\title{
The European Union's voice in the debate of the global governance of the internet
}

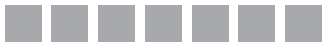 \\ Alicja Jaskiernia \\ UNIVERSITY OF WARSAW, POLAND
}

DOI: 10.19195/1899-5101.10.1(18).8

\begin{abstract}
This paper examines the European Union's policy regarding internet regulation. EU policy is examined regarding its role in the debate about internet governance at internal and global levels primarily. Based on the document currently accepted by European institutions, the paper first analyses the position of the European Union on key problems connected with the global debate on internet governance, such as the globalization of IANA and ICANN and increasing the role of other participants in the governance process. The paper attempts to reconstruct the current position of the European Union on internet governance and the vision and rules that the EU intends to promote on different platforms of the global discussion on the future of the internet.
\end{abstract}

KEYWORDS: policy, governance, European Union, European Commission, internet, Internet Corporation for Assigned Names and Numbers (ICANN), World Summits on the Information Society (WSIS).

\section{INTRODUCTION}

The Internet as a pillar of global communication, with all its related issues - from freedom of expression to fighting cybercrime - the management of the internet architecture and all other issues have entered into the process of internationalization. The regulation of information goods nowadays must be considered two different areas: binding rules introduced by states or traditional international organizations and mechanisms of private ordering, taking into account the very role of technology (Katzenbach, 2013, pp. 18-19) and civil society groups of interests. Kleinsteuber pointed out that a conventional law-making process conducted by a state and court system is not effective enough because the internet as a global medium "cannot be caged in by nation-states" (2004, p. 72). DeNardis (2014, p. 6) notes the huge implications of internet management on many issues like freedom of expression online, intellectual property rights and policy role of internet companies. The freedom of internet is not just threatened by state activities, but it also faces the 
danger of "privatized governance" (DeNardis, pp. 11-15; Kleinsteuber, 2004, p. 74). In such a situation the model of public policy in the scope of internet management has to be discussed on a global scale because it involved multiple stakeholders (media industries, internet industries, engineers, cybersecurity experts, private citizens and more) and has a huge impact not only on internet infrastructure and stability but also "directly reflect tensions among global information policy norms" (DeNardis, 2014, pp. 6, 15). The model of internet management, understood as "an ecology of choices that is shaping the Internet and its societal implications" (Dutton, 2016, p. 25) requires a common ground for a different mix of ideas coming from different actors. Some of them, like Russia's, China's or Indian governments, support a rather more multilateral model of control performed by organizations like the ITU, which has led to a debate between multistakeholder versus multilateral approaches to Internet governance (Dutton, 2016, p. 19; Kruger, 2016).

This article mainly attempts to present the EU's vision of internet government, adopted on 12 February 2014 in Communication of European Commission "Internet Policy and Governance - Europe's role in shaping the future of Internet Governance", as a formal policy position on internet governance (European Commission, 2014a). The European Parliament (EP) called on the Council and the Commission to create a strategy for democratic governance of the internet, and adopt:

An European Digital Habeas Corpus - protecting fundamental rights in a digital age, and develop the EU as:

a reference player for a democratic and neutral governance of the internet. (European Parliament, 2014)

The EP further notes the great need for creating a new model of internet governance developed jointly and based on the rules of a "social contract" by many interested parties. (European Commission, 2013a).

\section{THE CONCEPT OF GOVERNANCE}

The concept of governance reflects the fact that conventional media policy is no longer appropriate to solve many of the current challenges of communication and information flow, so informal structures of different actors are seen as more efficient. In the information age traditional media policy shift from a "now law vs. binding law" constellation to a more flexible soft law approach which is aimed at governments, business and civil society around the globe (Kleinwächter, 2016, p. 80). Katzenbach (2013, p. 20) explains that the governance perspective by decentering regulation, privileging neither public nor private ordering, allows to conceive regulation as a very complex process of ordering - private and public, formal and informal, discursive and material - wherein different sets of institutions and "bun- 
dles of entitlements" are stabilized, contested, transformed and dissolved, privileging neither statutory legislation nor forms of self-regulation. In such a process "sharing" of values and rules is "the basic pillar of Internet development", serving as a guideline for its governance (Kleinwächter, 2016, p. 75). For Mueller (2010, p. 15) the term governance is more attractive and accurate "because it is weaker then government; it denotes the coordination and regulation of interdependent actors in the absence of a political authority". Kummer (2016, p. 64) noted that the multi-stakeholder approach:

succeeded in creating a sense of community, a place where all participants felt comfortable discussing delicate issues. $(2016$, p. 64)

This perspective, focusing on the pluralization of actors involved in communication regulation, shows governance as a horizontal and vertical extension (Katzenbach, 2013, p. 3) of government, a general shift which involves more actors across, more policy issues, causes that varying interests in different incentives have to cooperate at the various points of the value chain (Katzenbach, 2013; Kummer, 2016; Dutton, 2016; Puppis, 2007). The term governance reflects the fact that in the absence of global government, decision-making becomes a highly complex procedure between national governments, global organizations, industry actors and NGOs. This fundamental recognition in discussing approaches to governance processes is confirmed by organizations such as the UN, International Telecommunication Union (ITU) or the European Union (EU). In this approach internet governance has to be recognized:

not as an object of control, but as the outcome of an ecology of choices made by many actors across a wide variety of arenas, from households to business, from technical standards committees to governmental jurisdictions around the world. (Dutton, 2016, p. 15)

\section{GLOBAL DEBATE ABOUT INTERNET GOVERNANCE}

The perception that one entity can utterly govern the internet is far from reality, because the internet cannot be recognized as single technical system that can be governed in a rational-comprehensive way (Dutton, 2016). DeNardis (2014, p. 222) explains that the "internet is governed" but not within nation-state boundaries or on one global platform but through the governance processes of global institutions or the policies of private companies, legal systems, regional norms and many "levers of control", virtual and invisible to the public. According to that the internet's governance fundamental issue is how "internet points of control as sites of global conflict over competing values" and how arrangements of technical infrastructure are arrangements of power (DeNardis, 2014, p. 7). These issues along with the phenomenon of privatization of functions traditionally performed by the state, now delegated from governments to corporations, are key issues "ate the heart of 
global internet governance" (DeNardis, 2014, pp. 6, 12-13). The complexity of these problems, along with the controversies largely revolving around the US relation to the ICANN (Dutton, 2016, p. 17) means that the international debate on the model of the internet governance is led in an atmosphere resembling the global dispute of the 20th century about the New World Information and Communication Order or even a:

clash of cultures between code making in the technical world and law making in the political world. But it was also clear that these two different spaces can no longer be clearly separated. (Kleinwächter, 2016, p. 78)

Nowadays the processes of management of the internet have gradually evolved from defining technical standards and the allocation of internet resources, to politics and regulation at a national and international level with respect to issues of protection from cybercrime, protection of competition, copyrights, privacy, e-commerce (European Commission, 2014a).

The formula of internet governance which was created at the moment of its birth as a decentralized web of computers of institutions in the U.S. and US Departments of Defense and Commerce, does not match the global nature of the internet and does not allow for the introduction of a sustainable model of its governance. So the development of internet governance has evolved from narrowly a defined perspective establishing "technical" standards by the Internet Engineering Task Force's (IETF) and IANA (The Internet Assigned Numbers Authority) and managing internet resources by ICANN (Internet Corporation for Assigned Names and Numbers) to a broader perspective. It has occurred that "internet governance is more that names and numbers", goes beyond the technical aspects and is relevant for public policy internet-related issues (Kleinwächter, 2016, p. 72). The global answer for this need was the UN involvement by creating the Working Group on Internet Governance (WGIG) platform WSIS (World Summits on the Information Society). The WSIS meetings have become the main platform for the discussion of internet governance and the place of "a battle over the soul of the Internet" (Mueller, 2010). This multistakeholder model involves many actors, however, the final decision-making capacity still remains in the hands of the governments of the UN member states (Kleinwächter, 2016, p. 85). The multistakeholder platform composed of representatives of all stakeholder groups is the IGF (Internet Governance Forum), but it is a body without any decision-making power (Kleinwächter, 2016, p. 86).

Irrespective of the role of these entities, key decisions in internet infrastructure and management remain in the hands of the ICANN - an organization established in 1998, as a non-profit organization based on the Affirmation of Commitments agreement with the U.S. government under contract with the U.S. Department of Commerce (DeNardis, 2014, p. 227). So, regardless of the quasi-multistakeholder ICANN model, key internet processes remain under pri- 
vate sector control (Kleinwächter, 2016, p. 85). ICANN's declared vision of "one world, one Internet" is supported by a mission which is enhancing the operational stability, security and global interoperability of the internet (ICANN, 2016).

Within the structure of the ICANN operate the IETF and GAC (Governmental Advisory Committee) composed of the representatives of governments, international organizations and global business. The IETF, guided by the credo "we reject kings, presidents and voting", is responsible for the internet's architecture. Participation in this structure is uncompensated and open to anyone. Milton Mueller explained the main difference between ICANN's governance and IETF, which concerns monopoly power over an essential resource which is the DNS root, which gives the ICANN "substantial power to control the domain name industry as whole" (Hurwitz, 2006). Due to the fact that the ICANN is de facto an entity responsible for managing the internet on a global scale but the entity itself is not - in accordance with many critics - global enough, the status and the functioning of the ICANN tend to be openly contested (Dutton, 2016; Kruger, 2016). DeNardis comments that the internet governance issue was:

played out locally in the United States but would have sweeping global implications. (2016, p. 6)

Contesting the formal status of ICANN as an entity conducting global functions without a legal international mandate (Fukuyama, 2006, p. 150) led the U.S. government to make a concession on the issue of globalization of some IANA and ICANN functions. These requests are strengthened by the objections of the "Americanization of the internet" and its "colonization" by governmental institutions of the U.S. (NSA or NTIA) and high-tech companies from Silicon Valley (Brown, 2013; Dutton, 2016, p. 11).

The states with the largest potential of network increase such as Russia, China or the developing African countries vote for the transfer of competences from ICANN to the International Telecommunication Union ITU (Kleinwächter, 2004) or for establishing a more multilateral or intergovernmental model (Dutton, 2015, p. 27). This is one of the contentious issues in the international debate, the same as the rights of communication as universal human rights, the rules on enhancing security in cyberspace and cybercrime prevention (WCIT, 2012). According to the The Montevideo Statement on the Future of Internet Cooperation, adopted by the Internet Society, the leaders of organizations responsible for global internet technical infrastructure called for globalization of ICANN and IANA functions, as well as catalyzing "community-wide efforts of the evolution of global multistakeholder internet cooperation", including all governments "participate on an equal footing" (IS, 2013). In March 2016 the ICANN Board approved the final IANA Transition Stewardship Proposal. After the 1st October 2016 ICANN continues to serve as the IANA Functions Operator under the contract with the five Regional Internet Registries (RIRs) (ICANN, 2016; Kruger, 2016, p. 6). 
Hurwitz (2006) notes that ICANN's role is only one of many governance issues, because the international community has recognized that "alternative models of governance exist" and ICANN's control was "replaced by a range of issues defined by a true need for effective international governance agenda". As a result, ICANN and the U.S. have lost their position "as dominant actors to a much more heterogeneous constellation" (Katzenbach, 2013, p. 8). In that "constellation" the WSIS and the IGF play a significant and increasingly important role on a global scale, as the only place for international-level political debate on internet governance (European Commission, 2013a). After the Tunis summit in 2005, some progress was reported in multistakeholder processes, although many questions still remain. Hurwitz (2006) argued that "the WSIS has been a great success" and the IGF plays the role of "a practical forum that fills an important void". Dutton sees the key role of the IGF on building linkages between different actors - both multilateral and multistakeholder, from governments, business, industry and civil society (Dutton, 2016, p. 46). But there is a real threat about plunging the global governance discussion into:

an international traveling circus $[\ldots]$ rather than organizations capable of making decisions. (Dutton, 2016, p. 44)

\section{INTERNET GOVERNANCE DEFINITION}

At the WSIS in Tunis in 2005 the concept of internet governance, developed by the WGIG, was adopted. In that definition internet governance can be treated as "the outcome" of many decisions provided by many actors (Dutton, 2016, p. 25). In accordance with this concept:

the international management of the Internet should be multilateral, transparent and democratic, with the full involvement of governments, the private sector, civil society and international organizations. It should ensure an equitable distribution of sources, facilitate access for all and ensure a stable and secure functioning of the Internet, taking into account multilingualism. (WSIS, 2005)

The WSIS participants "rediscovered the foundation of the Internet" which did not mean sharing control over ICANN with U.S. but searching for the solution how to do better ICANN and internet better "from bottom-up, looking for local maxima" (Hurwitz, 2006). There is a compulsion to enhance more participation and engagement in internet governance in "developing countries", "post-conflict" and "in situation of conflict" areas. Multistakeholder work is needed especially to deal with transnational issues that balance the various aspects of security in the context of human rights (EuroDIG, 2015). In that process, organizations such as the IGF could not be ignored both by governments or ICANN, so perhaps the future "government" or the "UN" of the global internet would not be ICANN but Internet Governance Forum (Dijk, 2010, p. 188). The IGF arose from the global dispute - 
mostly between the United Nations and U.S. administration - about the control of the root and was to create "a space for multistakeholder dialogue about global Internet policy" (DeNardis, 2014, p. 229). However, according to DeNardis (DeNardis, 2014, p. 229), the ability of this structure to exercise management functions is questionable, simply because the IGF is not an internet body but "a series of conferences with no policymaking authority" and is sometimes criticized for avoiding controversial subjects. Another controversial issue is the legitimacy of the civil societies' representatives and other non-governmental stakeholders to participate in policy decision processes at the global level:

Governments see themselves as the legitimate representatives of their states and their people. [...] In particular, representatives of civil society were seen by some governments as "noise makers" that do not have a legitimate mandate to represent constituencies. (Kleinwächter, 2016, p. 73)

Despite all the controversies mentioned above, the strengthening of WSIS impact and the IGF's mandate as internet governance platforms at the national, regional and international level are more and more exposed at the global level (Kleinwächter, 2016, p. 79). At the NETMundial in São Paulo Brazil, the representatives of governments, business, citizen organizations and experts from around the world adopted with "rough consensus", a Declaration of Internet Governance Principles (WCIT, 2014), which summarized, "globalized" and "multistakeholderized" the previous documents, constituting a common "base to measure good or bad behavior in cyberspace by governments, corporations and individual Internet users" (Kleinwächter, 2016, p. 82). Although at the IFG's meetings some of the participants express concerns that the rules "are too advanced for many governments to accept", however there were also optimistic voices about a "learning spiral" of mutual understanding. The NETMundial Statement evolved to encompass the following: human rights have become a permanent item on the work agenda of internet forums and recognition of multistakeholder processes are growing (IGF, 2015). But there still exists a lack of a common framework for resolving many controversial issues from the internet governance taxonomy, especially when it came to the challenges beyond the internet infrastructure (Kurbalija, 2016, p. 94). Another concern is a danger of balkanization of the internet and "to ensure that governance mechanisms remain as global as possible, and are not fragmented by nations and regions (Dutton, 2016, p. 39). Another potential risk is a centralization or domination of governance processes by some powerful actors such as governments or private industry.

\section{THE EUROPEAN UNION AND INTERNET GOVERNANCE}

Since the Green Paper 1987 on the establishment of the Single European Market in telecommunications (European Commission, 1987) and (European Commission, 1994), the European Union's policy in this particular area has developed in accord- 
ance with the rules of the market, but recently in the area of the internet, suggests that potential significant change has approached. As regards "governance on the internet", which means the regulation of internet-related public policy issues (Kleinwächter, 2016, p. 87), the EU worked out standards regarding various subjects including potential threats in cyberspace, protection of children and minors, personal data and privacy protection or cybercrime (European Commission, 2012, 2013c, 2013d; European Parliament, 2013, 2014).

In the first EU document about its role in internet governance, the Commission stated that the EU was an active and influential actor in the global discussion, especially in maintaining the principles and multi-stakeholder approach (European Commission, 2009). The next complex vision of internet governance was presented in project COMPACT (European Commission, 2014a). The EU's vision was based on five cornerstones: democracy and human rights protection, multi-stakeholder processes, confidence, and transparency. Internet governance, if it intends to remain one un-fragmented resource and to redeem standards as a sphere of civic responsibilities, needs a "new social contract" (European Commission, 2013a). Its new approach fosters the participation of many interested parties (Multi-stakeholder approach), based on solid technical architecture, which is the source of confidence (Confidence), fosters the transparency of governance of infrastructure (Transparent governance), pursuing the support of democracy and human rights as a main goal (Promote democracy and Human Rights) in the digital age. The EC recommends fostering internet governance "via issue-based dialogues, instead of through new bodies" (European Commission, 2014a). This is a functional-purposeful approach based on the rules from Tunis dated 2005 promoting the idea of the un-fragmented internet that is described by responsibility, transparency and trust, based on the multi-stakeholder model of governance.

\section{EUROPEAN COMMISSION COMMUNICATION ABOUT EUROPE'S ROLE IN INTERNET GOVERNANCE}

The Communication of European Commission "Internet Policy and Governance: Europe's role in shaping the future of Internet Governance" (European Commission, 2014a) deserves a detailed analysis for two reasons: first - the EU identifies there some important issues of internet governance, second - it presents, in a coherent way, the desirable governance model which may serve as an output proposal for further discussion in searching for global solutions.

The EU's vision of the internet is based on three basic values: homogeneity and uniformity of the internet as a "network of networks", obeying the same norms and provisions in virtual space as those binding in the real world and multilateral governance system (European Commission, 2014a). The EC supports a single, open, un-fragmented network and identifies transparency, inclusiveness and accountability as key principles for all multi-stakeholder internet governance processes. 
The main issues distinguished in the Communication relate to: a) the threat of fragmentation of the internet by different regulatory approaches of different countries, b) the necessity of globalization of the basic decisions concerning the internet including the actual globalization of ICANN and accepting the model of multilateral governance; $c$ ) the necessity to rebuild trust by proposing a catalogue of rules (values) which could be a global Decalogue of the network; d) a model of governance based on the idea of governance which in a constant and real manner assures the participation of many interested parties (European Commission, 2014a). The problems mentioned above are strictly connected with the model of functioning of the internet; therefore, it is necessary to analyze the standpoint of the Commission toward them presented in the Communication.

The main feature of the internet, underlined in the Communication as its undisputed value is the uniformity and indivisibility, expressed also by an objection against fragmentation balkanization of the internet. In the Communication it is stated that:

The European Union has always been committed to the internet as one single un-fragmented space, where all resources should be accessible in the same manner, irrespective of the location of the user and the provider. (European Commission, 2014a)

Censuring the network by blocking, slowing or discriminating against the content, services or applications and other "purely national approaches" may lead to the fragmentation of the internet and, as a consequence, threaten the free flow of information. In other words, the EC states that the control of the internet's technical architecture and control over the root should remain in the hands of ICANN if the internet is to remain as un-fragmented and open space providing social and economic development around the world.

Another subject of internet governance is not the question of who should control the technical infrastructure (the root), but how to balance some crucial values, like individual liberty, security or intellectual property rights and internet freedom (DeNardis, 2014, pp. 1-3).

We all believe the protection of fundamental rights is as important in the virtual world as it is in the real world - we stand united in Europe on this principle. (European Commission, 2013b)

These words from Ashton's speech means that axiology and the regulations in the network and the real world must remain consistent, although they may be enforced in a little different manner. According to the Communication the internet should be "subject to the same laws and norms that apply in other areas of our day-to-day lives" (European Commission, 2014a). The EC and EP have been endeavoring for many years to modernize legal frames regarding, in particular, cybercrimes, fighting the abuse of children on the internet, as has been mentioned above, and lately data and privacy protection (European Parliament, 2013), in particular 
in the context of the international flow of data and threat of mass surveillance (European Parliament, 2014).

The EC made an obligation to take further radical actions to effectively fight cybercrime and rebuild the trust in the network. This will be possible if effective mechanisms of combatting events that the Europeans think of as undesirable, hostile and harmful, will be taken up and introduced. Kroes, former EC Commissioner for the Digital Agenda for Europe, pointed out that:

although the internet is a different kind of place to the "real world" it should be underpinned by just the same values, priorities and interests as everything else. (European Commission, 2013a)

The EU announces that without promoting fundamental values, acceptance of the breach in the internet of fundamental rights undermines trust and is harmful both for individuals and for entire societies and economies of member states. The EU has clearly given a signal that it does not consider cyberspace as "wild fields" without any formal regulations. For this purpose, it is ready to "civilize" cyberspace by rebuilding trust in the internet, through the dialogue at global governance, which treats as "an essential prerequisite for a sustainable future for an open Internet" (European Commission, 2014a).

\section{THE EU'S INTERNET GOVERNANCE MODEL}

As regards the model of internet governance, the Communication supports the point of view presented globally by the EU on global forums, which agrees that optimal for internet management is the governance model, in which the dominant position is not attributed to any of the entities of the process. The EC constantly and firmly supports the model of internet governance with a real and equal participation of many interested actors. For this purpose it proposes the following standards for its model: transparency, real access to organizational processes and procedures and actual accountability. The model of internet policy should be based on:

an inclusive, transparent and accountable multi-stakeholder model of governance, without prejudice to any regulatory intervention that may be taken in view of identified public interest objectives. (European Commission, 2014a)

The processes should not exclude either governments or other public authorities whose powers and authorization come from democratic processes to fulfill their duties in public politics, if they are in accordance with common human rights. The governments of sovereign countries are obviously linked to the governance process. The sustainable governance model includes, in accordance with the Commission:

the role of public authorities to fulfill their public policy responsibilities consistent with human rights online. (European Commission, 2014a) 
A similar approach presented and adopted by the WSIS Summit in Tunis confirmed the legitimacy of governments and other public authorities, democratic mandates to make decisions in areas of internet governance on important social issues. The EC states, however, that balance the authorities bring an obligation to all stakeholders to share "a coherent set of Internet governance principles" (European Commission, 2014a). Reaching a compromise in key issues is not easy, which can be seen from the results of the debate in São Paulo in April 2014 (WCIT, 2014).

The EC considered that the governance process should also cover internet technical issues regarding protocols and roots, because they can have public policy implications, especially on some human rights such as privacy and freedom of expression (European Commission, 2014a). The Commission points out that despite the open character of the discussion on technical issues, the key decisions are often made by experts without the wide participation of interested entities. Therefore, the EC permits the co-regulation model in situations where the entire European internet industry supports the implementation of open standards (European Commission, 2014a). For this purpose, it proposes to organize workshops with the participation of international experts from the legal, ethical, social science, economic, international relations, and technical science branches. A specific and performable outcome of these meetings would be recommendations ensuring coherence between existing normative frameworks and new forms of internet-enabled norm-setting.

In the Communication the EC calls for the "globalization" of the ICANN, although it does not demand significant change by "taking over" the Internet by the United Nations (ITU). The EC supports the model with strengthening all participants of the multi-stakeholder governance, particularly the IGF. The EC considers that strengthening the "critically important role" of the IGF as a multi-stakeholder body helps the process of globalization of internet management. Due to this aim, the EC declares its active contribution to its "further evolution and improvement" (European Commission, 2014b).

It should be mentioned that during the past two decades several pan-European entities and global were created in the internet sector (Kleinwächter, 2016, p. 80). In Europe, new initiatives from industry and civil society, like EuroDIG, INHOPE or EuroISPA, have adopted a model of co-regulation and now play an increasingly important role in governance process at the pan-European level. EuroDig cooperates with many entities - from the Council of Europe, EBU and European IGF to academics and other NGO's. New bottom-up initiatives, like SEEDIG, created by and for stakeholders in South Eastern Europe (EuroDIG, 2015), have proved their potential of impact. The EC promotes these kinds of initiatives and calls upon stakeholders to further strengthen the sustainability of the model (European Commission, 2014a). For these purposes the EC established GIPO (Global Internet Policy Observatory) (European Commission, 2013e) as a platform to enhance the EU's engagement in global governance processes (European Commission, 2013e). 


\section{CONCLUSIONS}

A decade after the Tunis Summit, the global debate about the process of governance has not solved many problems caused by the internet's dramatic development, but shed light over them. Now the global community is mature enough to see some solutions. As a free and secure internet will not happen automatically, there may be a competent global network of "governors", following the logic of governance, which will be the best guarantee for a promising future for it (Kleinsteuber, 2004, p. 75). Many nations attempted to create new regulations toward some internet issues which have appeared online, such as stalking, online bullying, illegal file sharing or consumer fraud. The new users coming from developing countries brought new cultural experiences and norms. Adoption of the Tunis Agenda has not resolved all controversies and the challenges will grow. The European Union answer to these challenges is to defend the model of governance in which the internet is managed so far by ICANN and, at the same time, to propose a more inclusive, responsible and democratic vision of it. Contemporary internet governance is more complex because it involves technical mediation, "the privatization of conditions of civil liberties", enacted by traditional entities, private entities, and new global institutions (DeNardis, 2014, p. 242) considered that multistakeholderis $m$ may provide desirable balance of powers, under the condition that is not treated "as a value itself applied universally" but as a form of exploration for solutions in a particular context. The EC supports that kind of vision but it should see the deficits of detailed proposals and how to achieve the model of governance with the acknowledgement of threats that we have already experienced or that we foresee.

At the same time, the EC presents its intention to strive for maintaining traditional European values regarding fundamental human rights, shows the EU's efforts for Europeanization the rules and standards of internet governance processes. The key question is related to an attractiveness of such a vision of the internet governance model regarding both functional and axiological aspects, which may be acceptable for the democratic world of states, but can be contested by regimes which are already introducing "national models".

Finally, the EC has to also enhance the governance processes in the EU inside, if it would like to play - as it claims - a more important role "in the good governance of the Internet" (European Commission, 2014a). For that purpose the EU supports the IANA transition, globalization of ICANN, has created the GIPO and promotes the IGF and others civil society organizations. The next step in strengthening of governance processes should be using the multistakeholder approach for all of the EU's activities - both internal and external - focused on the internet. They should be conducted with transparency and openness, if the vision of an "inclusive, transparent and accountable multi-stakeholder model of governance" (European Commission, 2014a) of the internet has a chance to remain as global as possible. 
Alicja Jaskiernia

\section{REFERENCES}

Brown, I. (2013, Nov 1). Will NSA revelations lead to the Balkanization of the internet? The Guardian. Retrieved July 4, 2016 from http://www.theguardian.com/ world/2013/nov/01/nsa-revelations-balkanisation-internet.

DeNardis, L. (2014). Global War for the Internet Governance. New Haven: Yale University Press.

Dijk, J. (2006). The Network Society. Social Aspects of New Media. Thousand Oaks. New Delhi and Singapore: Sage.

Dutton, W.H. (2016). Multistakeholder Internet Governance? Michigan State University. Retrieved October 23, 2016 from http://www19.iadb.org/intal/intalcdi/PE/2016 /15984.pdf.

European Dialogue on Internet Governance (EuroDIG) (2015). Shaping the Internet Together. Messages from Sofia 4-5 June 2015. Retrieved July 4 2016, from http://www.eurodig.org/fileadmin/ user_upload/eurodig_Sofia/EuroDIG_A5.pdf.

European Commission (1987). Towards a Dynamic European Economy. Green Paper on the Development of the Common Market for the Telecommunications Services and Equipment, COM(87) 290 final.

European Commission (1994). Bangemann report: Europe and the Global Information Society. Brussels, 25-25 June, 1994.

European Commission (2009). Communication from the Commission to the European Parliament and the Council. Internet governance: The next step. Retrieved July 4, 2016 from http://eur-lex. europa.eu/LexUriServ/LexUriServ.do?uri=COM:2009:0277:FIN: EN:PDF.

European Commission (2010). Communication the European Parliament, The Council, The European Economic and Social Committee. A Digital Agenda for Europe, Brussels, 19.5.2010. Retrieved July 4, 2016 from http://eur-lex.europa.eu/legal-content/EN /TXT/PDF.

European Commission (2012). European Strategy for a Better Internet for Children. COM (2012)0196 final.

European Commission (2013a). Internet Governance: I want your views!. Retrieved June 4, 2016 from http://ec.europa.eu/commission_2010-2014/kroes/en/content/internet- governance-i-wantyour-views.

European Commission (2013b). Cyber security: An open, free and secure Internet. Catherine Ashton, High Representative of the Union for Foreign Affairs and Security Policy. Retrieved July 4, 2016 from http://europa.eu/rapid/press-release_SPEECH-12-685_en.htm.

European Commission (2013c). Joint Communication to the European Parliament, The Council, The European Economic and Social Committee. Cybersecurity Strategy of the European Union: An Open, Safe and Secure Cyberspace. Brussels, 7.2.2013 JOIN(2013)1 final. Retrieved July 4, 2016 from http://eeas.europa.eu/policies/eu- cyber-security/cybsec_comm_en.pdf.

European Commission (2013d). COM(2013) 846 Communication from the Commission to the European Parliament and the Council. Rebuilding Trust in EU-US Data Flows. Retrieved July 1, 2016 from http://ec.europa.eu/justice/data-protection/files/com_2013_846_en.pdf.

European Commission (2013e). Global Internet Policy Observatory - call for expressions of interest for a feasibility study. Retrieved July 4, 2016, from http://ec.europa.eu/digital- agenda/en/news/ global-internet-policy-observatory-call-expressions-interest- feasibility-study.

European Commission (2014a). Communication from the Commission to the European Parliament, The Council, The European Economic and Social Committee and the Committee of the Regions, Internet Policy and Governance Europe's role in shaping the future of Internet Governance, Brussels, 12.2.2014. Retrieved June 4, 2016 from http://eur-lex.europa.eu/legal-content/EN/TXT/PD $\mathrm{F} /$ ?uri=CELEX:52014DC0072\& from $=\mathrm{EN}$.

European Commission (2014b). European Commission position for Internet Governance Forum 2014, Istanbul 2-5 Sept., Retrieved July 4, 2016 from http://europa.eu/rapid/ press-release_MEMO14-513_en.htm. 
European Commission (2015). Internet Governance Forum 2015: Joint Declaration from European Commission Vice President Andrus Ansip and Members of the European Parliament. Retrieved October 23, 2016 from https://ec.europa.eu/digital-single- market/en/news/internet-governance-forum-2015-joint-declaration.

European Parliament (2013). Draft European Parliament Resolution on the proposal for a directive of the European Parliament and of the Council on the protection of individuals with regard to the processing of personal data by competent authorities for the purposes of prevention, investigation, detection or prosecution of criminal offences or the execution of criminal penalties, and the free movement of such data, (COM(2012)0010). Retrieved July 4, 2016 from http://www.europarl. europa.eu/ sides/getDoc.do?type=REPORT\&reference=A7-2013-0403\&language=EN.

European Parliament (2014). European Parliament Resolution of 12 March 2014 on the US surveillance programme, surveillance bodies in various Member States and their impact on EU citizens' fundamental rights and on transatlantic cooperation in Justice and Home Affairs (2013/2188(INI)). Retrieved July 4, 2016 from http://www.europarl.europa.eu/sides/getDoc.do?type=TA\&langua ge $=$ EN\&reference $=$ P7-TA-2014-0230.

Fukuyama, F. (2006). America at the Crossroads: Democracy, Power and the Conservative Legacy. New Haven, CT and London: Yale University Press.

Hurwitz, J. (2006). Who is WSIS; Who is IGF: The New Consensus-Based Internet Governance. Retrieved February 14, 2016 from https://www.researchgate.net/ publication/228191466_Whois_ WSIS_Whois_IGF.

ICANN (2015). Globalization of ICANN with Istanbul and Singapore Hub Offices. Retrieved June 4, 2016 from https://www.icann.org/news/blog/globalization-of-icann-with- istanbul-and-singapore-hub-offices.

ICANN (2016). Globalization of ICANN with Istanbul and Singapore Hub Offices. Retrieved July 14, 2016 from https://www.icann.org/resources/pages/welcome-2012-02-25-en.

IGF (2015). The 10th Internet Governance Forum (IGF) Chair's Summary, 10-12 November 2015, João Pessoas, Brazil. Retrieved February 14, 2016 from http://www.intgovforum.org/cms/10th\%20 IGF\%20Chairs\%20Summary_Finalv2.pdf.

IS (2013, Oct 7). The Montevideo Statement on the Future of Internet Cooperation. Retrieved July 4, 2016 from http://www.internetsociety.org/news/montevideo- statement-future-internet-cooperation.

ITU (2003). International Telecommunication Union. Retrieved July 4, 2016 from http://www.itu. int/wsis/documents/listing-all.asp?lang=en\&c_event=s|1\&c_type=all|.

ITU (2005a). International Telecommunication Union. Retrieved July 4, 2016 from http://www.itu. int/wsis/documents/listing-all.asp?lang=en\&c_event $=s\left|2 \& c \_t y p e=a l l\right|$.

ITU (2005b). The World Summit in the Information Society. Report of the Tunis phase, 16-18 November 2005. Retrieved July 4, 2016 from http://www.itu.int/wsis/ docs2/tunis/off/9rev1.pdf.

Katzenbach, Ch. (2012). Technologies as institutions: Rethinking the role of technology in media governance constellations. In: Just, N., Puppis, M. (eds.). Trends in Communication Policy Research. Bristol, UK and Chicago, USA: Intellect, pp. 117-138.

Katzenbach, Ch. (2013). Media Governance and Technology: From "Code is Law" to Governance Constellations. Abingdon and New York: Routledge.

Kleinsteuber, H.J. (2004). The Internet between regulation and governance. In: Möller, Ch., Amouroux, A. (eds.). The Media Freedom Internet Cookbook. Vienna: OSCE, pp. 61-75.

Kleinwächter, W. (2004). Beyond ICANN vs. ITU? How WSIS tries to enter the new territory of Internet governance. International Communication Gazette, 66, pp. 233-251.

Kleinwächter, W. (2016). Sharing decision making in Internet governance: The impact of the WGIG definition. In: Drake, W.J. (ed.). The Working Group on Internet Governance. 10th Anniversary Reflections. Published by APC, pp. 66-88. Retrieved October 23, 2016 from https://www.apc. org/en/system/files/IG_10_Final.pdf. 
Kruger, L.G. (2016). The Future of Internet Governance: Should the United States Relinquish Its Authority over ICANN? Congressional Research Service 7-5700. Retrieved October 23, 2016 from https://www.fas.org/sgp/crs/misc/R44022.pdf.

Kummer, M. (2016). A watershed moment in multilateral diplomacy: Adapting governance models to the 21st century. In: Drake, W.J. (ed.). The Working Group on Internet Governance. 10th Anniversary Reflections. Published by APC, pp. 33-64. Retrieved October 23, 2016 from https:// www.apc.org/en/system/files/IG_10_Final.pdf.

Kurbalija, J. (2016). The WGIG and the taxonomy of Internet governance. In: Drake, W.J. (ed.). The Working Group on Internet Governance. 10th Anniversary Reflections. Published by APC, pp. 89107. Retrieved October 23, 2016 from https://www.apc.org/en/system/files/IG_10_Final.pdf.

Marsden, Ch.T. (2004). Co- and self-regulation in European media and Internet sectors: The results of Oxford University's study. In: Möller, Ch., Amouroux, A. (eds.). The Media Freedom Internet Cookbook. Vienna: OSCE, pp. 76-100.

Mueller, M.L. (2010). Networks and States. The Global Politics of Internet Governance. Chicago: The MIT Press.

Puppis, M. (2007). Media governance as a horizontal extension of media regulation: The importance of self- and co-regulation. Communications, 32 (3), pp. 330-336.

Schaeffer, B.D., Gattuso, J.L., Rosenzweig, P., Inserra, D. (2014). Important Work to Be Done Before the U.S. Relinquishes Stewardship of ICANN. Retrieved February 14, 2016, from http://www. heritage.org/ research/reports/2014/03/important-work-to-be-done-before-the-us-relinquishesstewardship-of-icann.

WCIT (2012). World Conference on International Telecommunications (WCIT-12). Retrieved June 7 , 2016 from http://www.itu.int/en/wcit-12/Pages/default.aspx.

WCIT (2014, April 24). NETmundial Multistakeholder Statement. Retrieved July 9, 2016 from http:// netmundial.br/wp-content/uploads/2014/04/NETmundial-Multistakeholder-Document.pdf.

WSIS $(2005$, Dec). World Summit on the Information Society. Outcome Documents. Geneva 2003Tunis 2005. Retrieved July 1, 2016 from https://www.itu.int/ net/wsis/outcome/booklet.pdf. 